\title{
RYSZARD WAKSMUND
}

Uniwersytet Wrocławski

\section{OD SENTYMENTU DO WSTRETU. WSPOMNIENIA O DZIECIŃSTWIE PO 1989 ROKU}

Za ojca literatury wspomnieniowej uważa się św. Augustyna, którego Wyznania zawierają wzmianki o jego własnym dzieciństwie. Do tego etapu życia autor odnosi się z niechęcią, a przyczyną tego stanu rzeczy jest nie tyle dystans wobec wieku naiwności i słabości, co brak świadomości moralnej opartej na zasadach chrześcijańskich. Swe dzieciństwo postrzega zatem jako niemiły Bogu stan pogaństwa, z którego na szczęście udało mu się wyzwolić w dojrzałych latach. Nie darzy je zatem sentymentem, ale jawną niechęcią, bo jest to dlań czas zmarnowany, nieświadomy, niegodny prawdziwego powołania człowieka i wymagający przeto nadrobienia żarliwą religijnością chrześcijanina. Ten ton i stosunek do dzieciństwa kontynuować będzie nurt piśmiennictwa konfesyjnego aż po wiek XVII, zarówno w katolickiej jak i protestanckiej odmianie. Dopiero wyrosłe na gruncie oświeceniowego sentymentalizmu Wyznania Jakuba Rousseau przewartościują ten stan rzeczy. Dzieciństwo stanie się nie tylko ważnym okresem w życiu człowieka, ale i najbardziej fortunnym, gdyż nieświadomym trudów i zagrożeń, jakie zwykle przynosi dorosłe życie. Tak rozumieć je będzie również pokolenie romantyków, zwłaszcza polskich, dla których kraj lat dziecinnych nosić będzie jeszcze znamiona raju utożsamianego z poczuciem wolności i beztroski. Toteż Jerzy Cieślikowski ów subiektywnie przeżyty raj dzieciństwa rozpatrywał w kategoriach arkadii i świętości, raju „matki” - jako okres życia, którego prawdziwą wartość docenia się dopiero z perspektywy wieku dorosłego (Cieślikowski 1975: 158-160). Dzieciństwo wpisane zostało zatem w mit romantyczny jako jedna z jego odsłon, bez metaforycznych konotacji, związanych z sytuacją egzystencjalną i polityczną całych pokoleń (zob. Kubale 1984).

W XIX stuleciu wspomnienia o dzieciństwie będą stanowić często konieczny składnik literatury autobiograficznej od Franciszka Karpińskiego począwszy a na dziennikach Stefana Żeromskiego kończąc, jednak jako autonomiczna całość zaistnieją u nas w bogatej skali dopiero po odzyskaniu niepodległości i paradoksalnie staną się wyrazem nostalgii za okresem życia, który wielu autorom upłynął w czasach zniewolenia narodu. Chodzi, rzecz jasna, o bytowanie w kręgu rodzinnym, gdzie był czas na beztroskę i zabawę, ale gdzie pielęgnowano również patriotyzm jako odtrutkę na wpływ szkoły, traktowanej jako narzędzie germanizacji i rusyfikacji. Odjazd do szkół oznaczał nie tylko pożegnanie domu, ale i kres dzieciństwa, dającego się odzyskać jedynie na prawach mniej lub bardziej literacko obrobionej reminiscencji. Nieprzypadkowo zatem tego typu proza wspomnieniowa ma u nas swoją pierwszą złotą dekadę w latach 1923-1932, a może półtora - po rok 1936. Inicjuje je cykl nowelistyczny Marii Dąbrowskiej Uśmiech dzieciństwa (1923), za którym pojawiają się kolejno: Kornela Makuszyńskiego Bezgrzeszne lata (1925) Juliusza Kadena-Bandrowskiego Miasto mojej matki (1925), Zofii Nałkowskiej Dom nad tąkami (1925), Jerzego Bandrowskiego Wieś mojej matki (1929), Henryka Bezmaskiego Wspomnienia dzieciństwa (1929), Felicji Kruszewskiej Błękitny ogród (1928), Zygmunta Nowakowskiego Przylądek Dobrej Nadziei (1931). Jeszcze przed drugą wojną światową ukażą się: Melchiora Wańkowicza Szczenięce lata (1934), Zofii Szymanowskiej Opowieść o naszym domu (1935), Benedykta Hertza Ze wspomnień Samowara (1936) i Emila Zegadłowicza Uśmiech (1936). Zarówno dla Dąbrowskiej jak i Bandrowskiego, zdaniem Józefa Zbigniewa Białka: „epoka dzieciństwa w porównaniu z czasami współczesnymi stanowiła oazę spokoju i harmonii" (Białek 1987: 171).

Lata drugiej wojny światowej podtrzymały to nastawienie, o czym świadczy wydana w Londynie w 1942 roku książka Kraj lat dziecinnych, zawierająca wspomnienia 
m.in. Karola Estreichera, Kazimiery Iłłakowiczówny, Marii Kuncewiczowej, Ksawerego Pruszyńskiego i Zygmunta Nowakowskiego. Jak czytamy w Słowie wstępnym do pierwszego wydania: „Być może, że i w owej zbiorowej książce pisarzy nowej emigracji uderzy niejednego czytelnika, że polskość tej książki ciąży jeszcze wciąż silniej w kierunku Dniepru, niż w kierunku Odry, i wywodzi się raczej z polskiego dworu niż z polskiej wsi czy miasta" (Czermański 1987: 10).

Druga fala zainteresowań tą dziedziną pisarstwa pojawiła się u nas dopiero po okresie stalinizmu, zapewne jako zamaskowana pochwała rzeczywistości przedbolszewickiej. Mamy tu na myśli takie książki, jak: Jana Parandowskiego Zegar słoneczny (1953), Karola Estreichera Nie od razu Kraków zbudowano (1956), Jana Brzechwy Gdy owoc dojrzewa (1958), Jadwigi Kopeć Dziecko dawnej Warszawy (1958), Gustawa Morcinka Czarna Julka (1959) Jana Żabińskiego Co to było za dziecko (1960), Janiny Porazińskiej I w sto koni nie dogoni (1961). A więc autorów, których dzieciństwo przypadło na lata przed pierwszą wojną światową - na traumatyczny czas zaborów łagodzony atmosferą belle epoque. Jednocześnie dochodzi do głosu pokolenie wychowane w II Rzeczypospolitej, ale zmuszone przez cenzurę lub asekurację do ukrywania swych przekonań. Należą do niego tacy pisarze, jak np. Jerzy Andrzejewski (Książka dla Marcina, 1954) Stanisław Zieliński (Kiełbie we łbie, 1963) i Stanisław Lem (Wysoki Zamek, 1966). Józefa Radzymińska doświadczenia tej generacji skwitowała następująco: „Dziś myślę, jak szczęśliwym było moje dzieciństwo w Polsce Niepodległej, wolne od zła, z jakim stykały się dzieci urodzone podczas wojny, tworzące następne pokolenie. Moje wolne dzieciństwo sprawiło, że potrafiłam kochać swoje państwo bez zastrzeżeń, z czego potem skrystalizowały się idee, za które chciałam walczyć. Dzieci wojny i powojnia natomiast nie zawsze były pewne, w co mają wierzyć, zbyt często zmieniały się wtedy wartości i ideały" (Radzymińska 1998: 144).

Nie ma powodu, by rozwodzić się tu szerzej nad pokoleniem dzieci wojny, gdyż ich cierpienia zostały udokumentowane w niezliczonych źródłach. Może warto zaznaczyć jedynie, że w ostatnich trzech dekadach wzrosła niepomiernie ilość świadectw związanych z holocaustem, często spisanych przez osoby, które znalazły ratunek po aryjskiej stronie, a ponieważ wywodziły się najczęściej z zamożnych rodzin żydowskich, gdzie nie brakowało im niczego, tym bardziej boleśnie przeżywały tragedię wegetowania w getcie i zagładę swoich bliskich. W czasach PRL-u publikacje tego typu wpisywały się w nurt rozliczeń z Niemcami Zachodnimi, podobnie jak pieczołowicie gromadzone dowody hitlerowskiego barbarzyństwa względem polskich dzieci. Musiało upłynąć wiele czasu, zanim ofiary zdecydowały się na przedstawienie bardziej dogłębnych relacji, wykraczających poza zwykłe zeznania sądowe. Wzorem był tu bardziej Dziennik Anny Frank (1947), znany na całym świecie, niż nasz rodzimy, wydany czterdzieści lat później Pamiętnik Dawida Rubinowicza. Ale z biegiem czasu pojawiły się świadectwa retrospekcyjne, nie pozbawione epickiego rozmachu. Mam tu na myśli książkę Haliny Birenbaum Nadzieja umiera ostatnia (1967), będącą reakcją na proces Eichmanna. Jak wyznała autorka: ,Jednak we wstrząsających zeznaniach świadków brakowało mi czegoś. Brakowało czegoś bardzo istotnego - atmosfery nieustającej grozy codziennego bytowania pośród wszystkich okropności wojny. Oddychałam tą grozą niemal w ciągu sześciu lat, w których każda godzina była wiecznością albo godziną poprzedzającą tę ostatnią" (Birenbaum 1988: 5-6). Owa, wznowiona u nas w 1988 r., książka otwiera cały całą serię podobnych publikacji, jak np. Janiny Bauman Zima o poranku (1989), Stelly Müller-Madej Oczami dziecka (1991) czy Krystyny Chiger Dziewczynka w zielonym sweterku. Świadectwo Müller-Madej pozostaje w ścisłym związku ze słynnym filmem Spielberga Lista Schidlera (1993), co zaznaczono polskim wydaniu zmieniając tytuł książki na Dziewczynka z listy Schindlera. W przypadku wspomnień Chiger dodano tytuł $W$ ciemności - identyczny z filmem Agnieszki Holland, który był ich ekranizacją. Nie ma u nas chyba bardziej zauważalnego nurtu pisarstwa autobiograficznego niż związanego z holocaustem. Zostało ono zresztą gruntownie 
przebadane i skomentowane (zob. Kowalska-Leder 2009). Podejmowanie takiego tematu wiązało się niejednokrotnie z koniecznością odblokowania świadomości piszących, spychających przez długie lata przeżycia traumatyczne w niepamięć. Janina Bauman wyznała: „Minęło prawie czterdzieści lat nim poczułam się gotowa do napisania tej książki. W ciągu tych lat rzadko wspominałam przeszłość. Nigdy nie mówiłam o niej z Matką i Siostrą. Nigdy nie opowiedziałam córkom o moich przeżyciach. Wolałam zapomnieć. Przerażające obrazy powracały tylko w snach" (Bauman 1989: 5).

Za to zdecydowane novum w ostatnich trzech dekadach stanowią wspomnienia związane z deportacją dzieci polskich w głąb Związku Radzieckiego, zadając kłam obrazom z słusznie zapomnianego dziś opowiadania Janiny Broniewskiej dla młodzieży Siostrzeńcy ciotki Agaty (1946). Tamę milczenia przerwało ukazanie się krajowego wydania książki „W czterdziestym nas Matko na Sibir zesłali” (1989; pierwsze wyd. Londyn 1983) opracowanej przez Jana Tomasza Grossa i jego żonę, jak również wojennej odysei Hanki Ordonówny Tułacze dzieci (1990, reprint z 1948 r.). Nie trzeba było długo czekać a posypały się kolejne świadectwa, będące już całkowicie zindywidualizowanymi i rozwiniętymi relacjami na ten temat, że wymienię: Dzieciństwo na Syberii (2 serie), Julii Huber-Budzyńskiej Syberyjska dziatwa (1993), Anny Retmaniak Zapomniany smak truskawek (1994), Zbigniewa Fedusa Syberia wryta w pamięć dziecka (1997), Wandy Kocięckiej Oddajcie mi świętego Mikołaja (1999). We wspomnieniach Janiny Stopyry-Jabłońskiej Bez dzieciństwa (1997) znajdziemy rozdział pod tytułem, który mówi sam za siebie: $Z$ nieba do piekła.

W okresie PRL-u nie był to temat bezpieczny, o czym świadczą słowa Lubomira Czupkiewicza we wstępie do Opisu pobytu naszej rodziny na Sybirze od r. 1940 do r. 1946: „Pisałem go w tajemnicy przed rodzicami, aby ich nie martwić, bo za takie pisanie mogłem pójść do poprawczaka, a ojciec mógł stracić przeze mnie pracę. Dopiero kilkanaście lat później pokazałem swoje zapiski ojcu" (Czupkiewicz 2004: 5). Z przykrością trzeba stwierdzić, że nie znajduje on jak holocaust należytego odzewu w twórczości dla dzieci a jedyną zasługującą na uwagę pozycją w tym względzie są opublikowane przez wydawnictwo Literatura w serii „Wojny dorosłych - historie dzieci” Syberyjskie przygody Chmurki Doroty Combrzyńskiej-Nogali z 2014 roku. Przedtem bowiem jedynym, jeśli się nie mylę, tytułem beletrystycznym i to skierowanym do dorosłego czytelnika było opowiadanie Andrzeja Turczyńskiego Chłopiec na czerwonym koniu (1991).

Do rzadkości należą natomiast świadectwa dotyczące rzezi wołyńskiej. Jedno z nich opublikował Karol Rygier w książce Nieznane nazwiska czyli Dzieci wojny (2001), przytaczając opowieści rówieśników z sierocińca w Działoszycach, będących świadkami bestialskiego wymordowania ich bliskich przez Ukraińców. Musiało minąć piętnaście lat, by pojawił się kolejny tytuł, godny tej rangi problemu, a mianowicie Wotyń: historie dzieci ocalonych z pogromu - relacje opracowane przez Konrada Piskałę, Leona Popka i Tomasza Potkaja. Darmo szukać jednak takich opisów w książce Ryszarda Kłosińskiego pod wymownym tytułem Wołyńska golgota oczami dziecka (2009), co można tłumaczyć postawą autora, szukającego w myśl nauki Jana Pawła II, dróg pojednania z narodem ukraińskim. Poza tym tego typu publikacje, ukazujące się w wydawnictwach niszowych i nikłym nakładzie, pozostają niezauważalne i nie docierają do szerokiego ogółu czytelników. Trudno też wyobrazić sobie, by stały się przedmiotem zainteresowania w polskiej szkole, a tym bardziej spożytkowane przez pisarzy dla dzieci, jak to szczęśliwie się stało chociażby w przypadku osnutego na przeżyciach wojennych opowiadania Joanny Papuzińskiej Asiunia (2011), będącego autoadaptacją dwukrotnie opublikowanej książki wspomnieniowej Darowane kreski (1994, 2002), czy sporej liczby tytułów inspirowanych tematyką Holocaustu (Zob. Wójcik-Dudek 2017).

Na uwagę zasługuje książka Jerzego Mareckiego Dzieci '44. Wspomnienia dzieci powstańczej Warszawy wydana w okrągłą 70-tą rocznicę heroicznego zrywu Polaków przeciwko niemieckim okupantom, podobnie jak wspomnieniowa książka Warszawskie 
dzieci - z relacjami wychowanków prywatnej szkoły Anny Goldman, gdzie pod przykrywką szkolenia zawodowego uczono zasad konspiracji, małego sabotażu, strzelania, a nade wszystko odpowiedniej postawy etycznej w konfrontacji z okrucieństwem wojny. Inną perspektywę zawierają doświadczenia młodzieży hitlerowskich Niemiec, skłaniające wszelako autorów wspomnień do skruchy z powodu zauroczenia zbrodniczym systemem. Warto tu wymienić Alfonsa Hecka Dziecko Hitlera. Moja młodość wśród nazistów (2020) czy Melity Maschmann Bilans. Moje życie w Hitlerjugend. Bez usprawiedliwienia (2005). Kiedy Hitler doszedł do władzy, Alfons miał 9 a Melita 15 lat. W tym nurcie znalazł się także napisany przez Waltera Naumanna Dziennik młodego Niemca. Wspomnienia 19391940 (2018). Najnowszą kartę otwierają zwierzenia nastoletnich chłopców z Afryki, zmuszonych w drugiej połowie XX wieku do udziału w lokalnych wojnach. Można się o tym przekonać dzięki świadectwom Kongijczyka Luciena Badjoko (Bytem dzieckiem żołnierzem, 2007) czy Ishmaela Beaca z Sierra Leone (Wspomnienia dziecka-żotnierza, 2008). Traumę dziecięcego obserwatora wyrażają m.in. następujące słowa: „Wokół torturowano i zabijano ludzi. Byłem przerażony, ale widziałem, że nie mogę się odezwać, jeśli sam nie chcę zginąć. Zbierało mi się na wymioty" (Badjoko 2007: 55).

W ostatnich trzech dekadach światło dzienne ujrzały książki autorów, których dzieciństwo przypadło na okres PRL-u. Chodzi tu o pokolenie urodzone po wojnie, reprezentujące wyż demograficzny lat 1946-1964 a określane przez socjologów, interesujących się jego przydatnością dla pracodawców, mianem „boomersów” (zob, Kliombka-Jarzyna 2016). W warunkach polskich, gdzie komuniści narzucili społeczeństwu ściśle określony model egzystencji i rozwoju, powojenne dzieciństwo miało tyleż posmak idylli, co trudnej do zniesienia traumy. W pierwszym wypadku chodziło o poczucie bezpieczeństwa i dosytu bez świadomości kosztów tego stanu rzeczy, w drugim zaś o tęsknotę za prawdziwą wolnością, jakiej zaznało pokolenie ich rodziców w II Rzeczypospolitej, o czym dzieci dowiadywały się w domu. Nie do pozazdroszczenia był los tych dzieci, których rodzice byli tuż po wojnie więzieni, torturowani i szykanowani za opór przeciwko komunistycznej władzy, same zresztą również były szykanowane na różne sposoby. To im poświęcił Krzysztof Rajko książkę Wilczęta. Rozmowy z dziećmi Żotnierzy Wyklętych (2014). Literatura zarówno dla niedorosłych jak i dorosłych usłużnie utrwalała tę pierwszą wizję, która w świadomości czytelników kruszała jednak w miarę pojawiania się kolejnych kryzysów gospodarczych, odbijających się także na codzienności dziecka.

Kolejne generacje, wyrastające w klimacie rosnącego dobrobytu i cywilizacyjnego postępu obierają już przeszłość swych rodziców jako historyczną egzotykę, znaną z podręczników i telewizyjnych seriali. Z sentymentem czy pewną nostalgią, zrozumiałą gdy chodzi o ten rodzaj pisarstwa, wspominają swe dzieciństwo m.in. Krzysztof Rytka (Opowiastki wrocławskiego urwisa, 2006), Katarzyna Anna Weiss (Gra w kapsle czyli autolustracja PRL-u, 2008), Małgorzata Kalicińska (Fikołki na trzepaku, 2009), Gabriel Maciejewski (Dzieci peerelu, 2011). Była to zapewne, świadoma lub nie, reakcja na nurt demaskacyjny, traktujący dzieciństwo peerelowskie jako dalszy ciąg udręk zadanych temu pokoleniu po 17 września 1939 r. Wpisują się weń bez wątpienia takie książki, jak Juliana Kornhausera Dom, sen i gry dziecięce (1995), Antoniego Pieńkowskiego Dookoła pajaca (2004) czy Zofii Mitosek Pelargonie (2006). Nie chodzi tu tylko o cierpienia wywołane materialnym niedostatkiem, prostacką propagandą czy instytucjonalnym przymusem, ale przede wszystkim konieczność skrywania własnych odczuć i przekonań.

Najnowsze zjawisko to wypowiedzi autobiograficzne współczesnych celebrytów, na ogół zbyt zapracowanych, aby poświęcić czas na pisanie obszernych wspomnień. Z tego względu udzielają wywiadów, które stają się tworzywem książek mogących zainteresować ogół czytelników. Mam tu na myśli w pierwszym rzędzie opublikowane w 2013 roku przez Wydawnictwo Zwierciadło Cudowne lata. Opowieści o miejscach, w których dorastali, zredagowane przez Hannę Hajek i Zofię Fabianowską-Mycyk, gdzie znalazły się zwierzenia 
m.in. takich sław, jak Henryk Chmielewski, Urszula Dudziak, Wojciech Fibak, Andrzej Grabowski, Marek Niedźwiecki, Małgorzata Niezabitowska, Jan Peszek, Cezary Pazura. Przeważają w tym gronie aktorzy, a wszyscy widnieją ponadto na kolorowych fotografiach Łukasza Gawrońskiego. Natomiast w tomie przygotowanym przez Joannę Rolińską Raz $d w a$ trzy za siebie. Rozmowy o dzieciństwie, z tego samego roku, dominują nazwiska literatów, mimo że niektórzy z nich, jak Joanna Papuzińska czy Józef Hen, wypowiedzieli się już obszernie na ten temat we własnych książkach. Jak twierdzi autorka, zbiór ten: ,jest próbą stworzenia panoramy dzieciństwa dwudziestego wieku, próbą składającą się z czternastu indywidualnych perspektyw" (Rolińska 2013: 7). Na uwagę zasługuje kunsztowna oprawa edytorska, gdzie uwagę przyciągają udostępnione przez Małgorzatę Baranowską, ostatnią z interlokutorrek, stare pocztówki z belle epoque przedstawiające idylliczne sceny dziecięce. W jakiejś mierze o temat dzieciństwa zahaczają wypowiedzi rozmówców Ewy Gil-Kołakowskiej i Henryka Szareyki z książki Opowieści wigilijne o wieczerzy, kolędach, Herodzie... (2011). Znajdziemy tu takie nazwiska, jak: Anna Dymna, ks. Tadeusz Isakowicz-Zaleski, Jan Miodek, Danuta Stenka, Kazik Staszewski, Beata Tyszkiewicz, Magdalena Zawadzka.

Nie sposób pominąć również przygotowanego przez Małgorzatę Puczyłowską tomu Być dzieckiem legendy, gdzie portrety nieżyjących już aktorów i ludzi estrady nakreślili ich potomkowie. Znalazły się tu m.in. takie sławy, jak: Kazimierz Brusikiewicz, Krzysztof Klenczon, Ada Rusowicz, Kasia Sobczyk, Aleksandra Śląska, Roman Wilhelmi i Andrzej Zaucha. Nie był to pomysł oryginalny, gdyż w okresie PRL-u z równą starannością edytorską potraktowano opracowane przez Stefana Henela Godziny zwierzeń. Wspomnienia córek i synów o ich sławnych i zasłużonych rodzicach (1983), poprzedzając każdą wypowiedź suchym biogramem. W grubym tomie znalazły się z jednej strony sylwetki uczonych, pisarzy i artystów, jak np. Tadeusz Żeleński (Boy), Stanisław Estreicher, Ludwik Krzywicki, Rudolf Weigl, Stanisław Wyspiański, z drugiej zaś polityków, działaczy i żołnierzy, wśród których figurują m.in. Bolesław Bierut, Stanisław Dubois, Eugeniusz Kwiatkowski, Karol Świerczewski, Franciszek Żwirko. Utrzymane w sepii fotografie i druk miały stwarzać klimat rodzinnego tableau. Chyba nie ostatnim słowem w tej materii była autobiograficzna książka Moniki Jaruzelskiej z 2013 roku Towarzysz Panienka, opublikowana w wydawnictwie Czerwone i Czarne. Na tym tle bardziej korzystnie, także z uwagi na staranność stylu, wypadają klasyczne książki wspomnieniowe, jak Zofii Nałkowskiej Mój ojciec i Ewy Curie o jej sławnej matce. One to mogły ośmielić Tomasza Lema, syna Stanisława, do sporządzenia podobnego portretu (Awantury na tle powszechnego ciązenia, 2009).

W naszym przeglądzie nie może zabraknąć książki Beaty Tadli Pokolenie '89 czyli dzieci PRL-u, wydanej w 2009 roku. Autorka dobrała tu ludzi urodzonych pod koniec lat 60-tych i w latach 70-tych. „Wspomnienia moich rozmówców mają wiele wspólnych elementów - wyjaśniała. - Guma do żucia Donald, puszka coli czy kubańskie pomarańcze u wszystkich uruchamiają ciąg podobnych skojarzeń" (Tadla 2009: 11). W jej galerii znaleźli się m.in. Piotr Adamczyk, Dorota Gawryluk, Roman Giertych, Piotr Kraśko, Andrzej Piasek Piaseczny, Monika Richardson, Jarosław Wałęsa. We wszystkich tego typu publikacjach, jakie ukazały się w ostatnich trzech dekadach, obowiązuje na ogół porządek alfabetyczny, a więc niehierarchiczny. Trzeba przy tym zaznaczyć, że większość z nich ukazuje się na kredowym lub półkredowym papierze, z bogatą oprawą graficzną, uwzględniającą nie tylko zdjęcia bohaterów aktualne i z okresu dzieciństwa, ale niekiedy także ilustracyjne, dotyczące życia obyczajowego i politycznego. Jak słusznie stwierdziła Marta Cobel-Tokarska:

Dzisiejsi „trzydziestolatkowie” mają zupełnie inny punkt odniesienia, jeśli chodzi o przeszłość niż ludzie starsi. Nie doświadczyli w PRL zbyt wielu złych rzeczy, a jeśli nawet, to raczej nie za sprawą systemu. Nie była to ich dorosła rzeczywistość, w której musieliby dokonywać trudnych wyborów i ponosić ich konsekwencje. Jednocześnie lata osiemdziesiąte to jedyny PRL, jaki znają. Wspominając dzieciństwo, wspominają PRL; te wspomnienia są dla nich ważne, czynią ich bowiem świadkami pewnej historycznej epoki, której młodsi od nich już osobiście nie doświadczyli i nie mają szansy 
doświadczyć. Data urodzenia może nawet dawać swoiste poczucie wyższości - „trzydziestolatki” mogą wspominać PRL zupełnie bezkarnie, mając przewagę zarówno nad starszymi (którzy na taką niewinność nie mogą sobie pozwolić), jak i młodszymi (którzy nie mają czego wspominać) (Cobel-Tokarska 2015: 128).

Za signum temporis należy uznać lawinę książek wspomnieniowych traktujące o traumach dzieciństwa związanych nie tyle z maltretowaniem fizycznym, co znamy już $\mathrm{z}$ autobiografii Maksyma Gorkiego, ile z wykorzystywaniem seksualnym przez dorosłych, zwłaszcza z kręgu domowego. Problem ten sygnalizowała już Alice Miller w głośnej książce Mury milczenia. Cena wyparcia urazów dzieciństwa (1991), odwołując się m.in. do świadectw historycznych (etapy edukacji seksualnej Ludwika XIII), psychoanalizy Freuda, Czarnej Pedagogiki oraz traumatycznych doznań Wirginii Woolf, zmuszanej zabaw seksualnych aranżowanych przez jej dużo starszego przyrodniego brata - Georga. Była to epoka, która nieświadomość dziecka w sprawach erotyki wyniosła na piedestał tak wysoko, że nawet niewinne zabawy maluchów w doktora, związane $\mathrm{z}$ oglądaniem i porównywaniem swego przyrodzenia uważano za ohydne, podobnie jak masturbację i przedwczesne inicjacje seksualne nastolatków. Inna sprawa to praktyki homoseksualne młodzieży kształcącej się w systemie internatowym, o czym można przekonać się z niejednych zwierzeń. Wystarczy wskazać na autobiograficzną opowieść Hansa-Georga-Behra Prawie dzieciństwo (2002), której autor - syn niemieckiego oficera, prominentnego hitlerowca, trafił do szkoły klasztornej; tam też był seksualnie molestowany przez nauczyciela-zakonnika.

Współczesna literatura wspomnieniowa nie traktuje tych spraw jako tabu, przynajmniej w książkach kierowanych do dorosłego czytelnika. Niektóre wpisują się bowiem chociażby w okrucieństwa wojny, jak świadczy o tym wyznanie Niemki - Tilli Schulze, która w wieku 12 lat została zgwałcona przez sowieckich żołnierzy: „Zdzierają ze mnie ubranie, rozdzierają sukienkę z przodu, drapią mnie ich szorstkie owłosione ręce. Śmierdzą kwasem i wilgocią, gorzej niż jakikolwiek przepełniony nocnik." (Schulze, Collie 2009: 219). Ale sprawcą seksualnej przemocy może być też ktoś z kręgu rodzinnego, o czym świadczą wyznania cygańskiego chłopca, napastowanego wielokrotnie prze własnego stryja a nie mającego pojęcia, co znaczy słowo „sex” (Walsh 2011). Zachętą do ujawniania tego rodzaju faktów są z pewnością akcje organizowane przez różne stowarzyszenia broniące praw dziecka i mające własne wydawnictwa. Do jednych z nich należy z pewnością seria „Pisane Przez Życie”, w ramach których ukazały się takie tytuły m.in., jak: Shy Keenan Zniszczone dzieciństwo (2010), Vanessy Steel Ukarana (2011), Sally East Czarne dni małej Sally (2013), Toni Maguire Tylko nie mów mamie (2015). Przeważają pozycje z importu, ale nieśmiało pojawiają się książki polskich autorów, jak np. Kato-tata Halszki Opfer (2017), która wyznała:

Po wydaniu książki spotkałam się z dwiema odmiennymi reakcjami. Pierwsza to taka, że moja książka wzbudziła wielkie emocje, ponieważ w zasadzie nie ma w Polsce zbyt wiele literatury na temat molestowania dzieci. A jeśli jest, to nie ma tam aż tak drastycznych scen. Słowo „molestowanie” zawsze było dla mnie wyrazem zbyt delikatnym. Raczej kojarzyło się z tak zwanym „złym dotykiem", a to nie oddaje dramatu, jaki przeżywa dziecko. Starałam się dokładnie opisać nie tylko samo molestowanie, ale także moje związane z tym odczucia i emocje. Czytelnicy byli oburzeni postawą moich rodziców. Wstrząśnięci tym, że można swoim dzieciom zgotować piekło i nie ponieść w związku z tym żadnych konsekwencji. Bałam się wydać książkę pod moim nazwiskiem, ponieważ bywa tak, że nie myśli się o pomocy ofierze, a raczej koncentruje się na sprawcy, któremu niestety często się współczuje. Było mi bardzo miło, kiedy dowiadywałam się, że zrobiłam wspaniałą rzecz, pisząc książkę, gdyż być może pomoże ona ofiarom przemocy seksualnej, ale także alkoholizmu, przemocy fizycznej i psychicznej (Opfer 2009).

Mając na względzie tego rodzaju świadectwa, trudno uwierzyć w arkadyjskość świata dziecięcego. Mit romantyczny, ukształtowany na gruncie poezji, okazał się niezwykle produktywny w twórczości wybitnych pisarzy - od Goethego po Prousta, ale 
w tym wypadku staje się całkiem bezużyteczny i kto wie, czy nie przesłania bezmiaru krzywd wyrządzanych dziecku w domowym zaciszu, co dostrzegł dopiero Fiodor Dostojewski jako autor Biesów (dziewczynka zhańbiona przez Stawrogina). We współczesnym świecie krzywdzenie dziecka nie ogranicza się tylko do kwestii seksu, ale dotyczy również maltretowania, dręczenia psychicznego, skazywania na głód, żebractwo i włóczęgostwo, wystawiania na sprzedaż, porywania przez gangi dla pozyskiwania przeszczepów, zmuszania do morderczej pracy, do kradzieży i zabijania, a w najłagodniejszej postaci - realizowania ambicji rodziców (dzieci-zachcianki, dzieci mediów) (zob. Zwoliński 2012). Ale owo spectrum zagadnień znacznie wykracza poza przedziały czasowe i być może będziemy zmuszeni uznać je za zjawisko uniwersalne, związane tyleż z warunkami zewnętrznymi, co naturą ludzką, zabłąkaną między niebem i piekłem.

\section{Bibliografia}

BADJOKO, L. (przy współpracy K. Clarens) (2007). Byłem dzieckiem żotnierzem (przeł. K. Dolatowska). Warszawa: Wydawnictwo Muza.

Bauman, J. (1989). Zima o poranku. Kraków: Znak.

BiAŁeK, J. Z. (1987). Literatura dla dzieci i młodzieży w latach 1918-1939. Zarys monograficzny. Materiaty. Warszawa: Wydawnictwa Szkolne i Pedagogiczne.

Birenbaum, H. (1988). Nadzieja umiera ostatnia. Warszawa: Czytelnik.

CieśLIKowski, J. (1974). Literatura i podkultura dziecięca. Wrocław: Ossolineum.

Cobel-ToKarska, M. (2015). Ostatnie pokolenie PRL: pamięć „trzydziestolatków”. W: K. Górniak, T. Kanasz, B. Pasamonik, J. Zalewska (red.), Socjologia czasu, kultury i ubóstwa (s. 126-144). Warszawa: Wydawnictwo Akademii Pedagogiki Specjalnej.

Czermański, Z. i in. (1987). Kraj lat dziecinnych. Londyn: Puls Publications.

Czupkiewicz, L. (2004). Opowieść polskiego chłopca. Komorów: Antyk Marcin Dybowski.

KliombKa-Jarzyna, J. i in. (2016). Pokolenia - co się zmienia? Kompendium zarzadzania multigeneracyjnego. Warszawa: Wolters Kluwer Polska.

KowALSKA-Leder, J. (2009). Doświadczenie Zagłady z perspektywy dziecka w literaturze dokumentu osobistego. Wrocław: Wydawnictwo Uniwersytetu Wrocławskiego.

Kubale, A. (1984). Dziecko romantyczne. Szkice o literaturze. Wrocław: Ossolineum.

OPfER, H. (2009). Wywiad: Gdy mój tata byt pijany. Pozyskano z: https://www.papilot.pl/ zycie/ludzie/3034/wywiad-gdy-moj-tata-byl-pijany-ogarniala-go-dzika-zadza-seksu.

RADZYMiŃsKa, J. (1998). Podróż do początku. Warszawa: PIW.

Rolı́́sKa, J. (2013). Raz dwa trzy. Rozmowy o dzieciństwie. Warszawa: G+J Książki.

Schulze, T., Lorna C. (2009). Marionetka historii. Opowieść o życiu w hitlerowskich Niemczech i pod sowiecka okupacja (przeł. B. Markiewicz). Katowice: Videograf II.

Tadla, B. (2009). Pokolenie '89, czyli dzieci PRL-u w wolnej Polsce. Warszawa: G+J Książki.

Walsh, M. (2011). Cygański chłopiec. Byłem obcy wśród swoich (przeł. T. Tomczyńska). Warszawa: PWN.

WóJCIK-DudeK, M. (2017). (Wy)czytać Zagładę. Praktyki postpamięci w polskiej literaturze XXI wieku dla dzieci i młodzieży. Katowice: Uniwersytet Sląski.

Zwoliński, A. (2012). Krzywdzone dzieci. Zagrożenia współczesnego dzieciństwa. Kraków: WAM. 


\section{RYSZARD WAKSMUND}

\section{FROM SENTIMENT TO REVULSION: CHILDHOOD MEMORIES AFTER 1989}

In the Romantic period, the myth of the paradisiacal and undefiled childhood was formed, which survived until the 20th century also in autobiographical writing. Gradually, however, critical testimonies connected with the experiences of World War II, especially the Holocaust, began to surface, followed by the current of memoirs of authors from the postwar generation, disillusioned with the communist reality. Another generational caesura was the martial law, with an ambivalent scale of feelings, reflected mainly in memoirs of today's celebrities. However, the final blow to the romantic myth is being dealt by testimonies published today that areproving the sexual harassment of children by adults. And this is not the only evidence of adults' cruelty. 